\title{
PKM virtual: Model dan strategi gerakan sosial pandemi Covid 19 masyarakat Jatimulyo Kabupaten Tulungagung
}

\author{
Ubaidillah $^{1, *}$, Ariski Titis Ainun Nisai ${ }^{1}$ Neli Ana Sapitri ${ }^{1}$ \\ ${ }^{1}$ UIN Sayyid Ali Rahmtullah, Jln. Mayor Sujadi Timur 46 Plosokandang, Indonesia \\ *) Korespondensi (e-mail: ubaidillah830@gmail.com) \\ Received:8-September-21; Revised: 6- November-21; Accepted: 8-November-21
}

\begin{abstract}
The COVID-19 pandemic that has hit Indonesia for approximately 2 years has had an impact on the community's economy, education, and religion. The purpose of this research is to help food consumption security for people affected by the COVID-19 pandemic. The method used in this research is virtual service by using the social assistance and social services approach virtually. The results of this study are the first to distribute aid in the form of food to people affected by the COVID-19 pandemic, especially to the elderly. As well as social services in the form of spraying disinfectants in the community through the head of the RT, distributing masks and hand sanitizers to the community as an effort to prevent the transmission of COVID-19. Second, efforts to create a healthy environment as an effort to minimize the transmission of COVID-19. Third, many people still think that the transmission of COVID-19 can be avoided simply by staying away from infected people, even though this virus can be transmitted through particles attached to objects around us, sneezing, and coughing.
\end{abstract}

Keywords: Social Assistance; Social Service; Disinfectant; Covid 19.

\begin{abstract}
Abstrak
Pandemi COVID-19 yang melanda Indonesia kurang lebih selama 2 tahun telah berdampak pada ekonomi masyarakat, pendidikan, dan bidang agama. Tujuan dari penelitian ini untuk membantu ketahanan konsumsi pangan untuk masyarakat yang terdampak pandemi COVID-19. Metode yang digunakan dalam penelitin ini adalah pengabdian secara virtual dengan menggukan pendekatan bansos (bantuan sosial) dan baksos (bakti sosial) secara virtual. Hasil dari penelitian ini pertama penyaluran bantuan berupa bahan pangan kepada masyarakat yang terdampak pandemi COVID-19 terutama kepada lansia. Serta bakti sosial berupa penyemprotkan desinfektan dilingkungan masyarakat melalui ketua RT, pembagian masker dan hand sanitizer kepada masyarakat sebagai upaya untuk mencegah penularan COVID-19. Kedua, upaya untuk menciptakan lingkungan yang sehat sebagai upaya menimalisir penularan COVID-19. Ketiga, masyarakat masih banyak yang berfikir bahwa penularan COVID-19 bisa dihindari hanya dengan menjauh dari orang terinfeksi, padahal virus ini dapat menular melalui partikel-partikel yang menempel pada benda disekitar kita, bersin, dan batuk.
\end{abstract}

Kata kunci: Bansos; Baksos; Desinfektan; Covid 19.

How to cite: Ubaidillah, U., Nisai, A. T. A., \& Sapitri, N. A. (2021). PKM virtual: Model dan
strategi gerakan sosial pandemi Covid 19 masyarakat Jatimulyo Kabupaten
Tulungagung. Penamas: Journal of Community Service, 1(2), 107-115.
https://doi.org/10.53088/penamas.v1i2.143




\section{Pendahuluan}

Di masa pandemi covid-19 seperti ini banyak masyarakat yang kurang mampu dan berharapkan uluran tangan dari pemerintah. Apabila dalam hal kestabilan pangan terutama bagi masyarakat yang tidak mampu, terutama keluarga yang berada pada kondisi sosial ekonomi rendah (Tim Pengendali Pelaksanaan Penyaluran Bantuan Sosial secara Non Tunai, 2019). Sedangkan untuk pencegahan penularan COVID-19 kami dari mahasiswa berinisiatip pejerjasama dengan pihak desa terkait bansos dan baksos. Maka dari itu kami mengadakan kegiatan bansos dan baksos seperti untuk meningkatkan kestabilan dan tindakan pencegahan. Penualuran ini kami maksudkan untuk membantu masyarakat yang terkena dampak pandemi covid-19.Pada saat ini Indonesia sedang beduka karena dilanda oleh musibah pandemik COVID-19.

Pandemi menyebabkan bermacam masalah muncul, seperti meningkatnya kemiskinan yang disebabkan banyak orang yang kehilangan pekerjaan, dunia pendidikan menjadi kurang efektif, dan korban yang bertambah setiap harinya. Hal ini dibuktikan dengan menurunnya tingkat pendapatan masyarakat secara dratis, misalnya hasil laut maupun ladang sama mengalami turun harga yang menjadikan kehidupan masyarakat semakin sulit (Tapung, Regus, Payong, Rahmat, \& Jelahu, 2020). Pandemi ini menyebabkan banyak korban karena terinfeksi virus pada saluran pernafasan. Dampak yang disebabkan dari pandemi covid-19 ini tidak hanya korban yang terinfeksi melainkan seluruh dunia. Bagaiman tidak mengkibatkandampak yang sangat merugikan. Perekonomian menjadi lumpuh, pendaptan setiap orang menurun tanpa pandang buluh, terjadi PHK besar-besaran dimana, kelangkaan masker, dan handsanitizer. Sehingga kita tidak dapat terbelenggu dalam kepanikan dan harus berpikir bagaimana kedepannya.

Salah satu yang terdampak yaitu masyarakat desa yang di PHK dari instansiinstansi perusahaan terkait. Sehingga menimbulkan permasalahan pertama penurunan tingkat pendapatan penduduk kurang seiring terjadinya pandemi. Kedua masalah penanganan pencegahan COVID-19. Maka masalah ini harus diselesaikan, salah satunya dengan memberikan bantuan sosial yang sasarannya masyarakat kurang mampu dan lansia. Bansos sendiri diartikan bantuan yang diberikan pemerintah yang ditujukan kepada masyarakat yang kurang mampu melalui desa, sedangkan baksos dapat diartikan sebagai kegiatan hasil rasa kemasuaiaan antara sesama, diera Pademi COVID-19 seperti sekarang program baksos yang bisa dilakukan adalah seperti penyemprotan disenfektan, pemberian masker, hand sanitizer, dan sosialisasi dalam upaya mencegah penularan COVID-19.

Kami selaku mahasiswa tergerak untuk melaksanakan kegiatan bansos dan baksos yang berupa bantuan sembako yang diberikan kepada lansia dan masyarakat yang kurang mampu. Sedangkan baksos melaksanakan penyemprotan desinfektan. Penyemprotan desinfektan ini berkoordinasi dengan pihak desa. Dari pihak RT dan RW juga ikut antusias dalam penyemprotan desinfektan ini. Pihak karangtaruna desa dan pihak pengamanan seperti Bhabinkamtipmas dan Babinsa juga antusias menyemprotkan desinfektan di masa pandemi sekarang ini, banyak 
masyakat yang menilai kegiatan seperti bansos dan baksos itu hal yang bermanfaat bagi mereka. Tentunya dapat meringankan beban orang tidak mampu dan membenteni dari penularan penyakit pernapasan dengan cara penyemprotan desinfektan.Rumusan masalah yaitu :1) Bagaimana strategi bansos dilakukan di tengah covid-19. 2) Bagaimana baksos dilakukan di tengah isu penolakannya.

\section{Metode Pengabdian}

Tujuan dari dilaksanakannya webinar dengan tema "Bansos \& Baksos Bentuk Keperdulian di Masa Pandemi COVID-19" adalah pertama, memberikan sedikit bantuan sembako untuk meringankan beban orang yang tidak mampu terutama para lansia. Karena difokuskan pada lansia yang ada di Desa Jatimulyo Kecamatan Kauman Kabupaten tulungagung. Kedua, mengajak warga agar tetap waspada terhadap penyebaran COVID-19 sebagai upaya menjaga kesterilan lingkungan desa dari virus. Dengan cara penyemprotan desinfektan yang dikoordinir dari kepala desa dan bekerjasama dengan pihak berwajib agar terlaksana dengan tertib dan memenuhi protokol kesehatan. Adapun teknis bansos dan baksos, sebagai berikut:

Pertama, Koordinasi kepada pihak desa terkait siapa saja yang berhak menerima bansos.Kedua, Melihat data di Kantor Desa data orang yang tidak mampu yang diutamakan lansia. Ketiga, Penyebaran surat dibantu oleh pihak desa, bahwasannya akan dilaksanakan bansos dan baksos berupa pembagian sembako dan penyemprotan desinfektan. Keempat, meminta bantuan ketua RT untuk menyampaikan kemasyarakat setempat bahwa akan ada penyemprotan desinfektan beserta pembagian sedikit sembako.

Pelaksanaan kegiatan pengabdian setelah menyusun teknis pelaksanaan bersama teman-teman, tidak lupa berkoordinasi dengan ketua RT dan teman-teman karangtaruna yang ikut membantu. Adapun pihak keamanan yang ikut membantu yaitu dari pihak Bhabinkamtipmas dan Babinsa. Kegiatan dilakukan pada tanggal 22 Februari 2021 pukul 06.00- selesai. Untuk penyemprotan desinfektan berkumpul di Kantor Desa, bersama perangkat desa kita membagi cairan desinfektan kepada masing-masing ketua RT. Setelah itu, teman-teman dibagi menjadi beberapa kelompok untuk menyebar disetiap RT. Ada yang bertugas menyemprotkan desinfektan dan ada yang membagikan bansos berupa sembako. Beberapa foto dokumentasi yang diambil oleh divisi media berupa video dan foto sebagai bukti telah dilaksanakannya rencana yang sudah disusun.

Sasaran dari kegiatan bansos dan baksos ini yaitu masyarakat kurang mampu dan sekitar rumah warga yang disemprot desinfektan. Dalam hal meningkatkan dan membangkitkan rasa kemanusiaan antar sesama warga dalam pemberian sedikit bantuan dan mencegah merebaknya penyakit pernapasan yang tema "Bansos \& Baksos Bentuk Keperdulian Di Masa Pandemi COVID 19”, maka target bansos ialah agar bisa meringankan sedikit beban dalam hal pangan. Sedangkan baksos seperti desinfektan untuk mencegah dan peningkatan kewaspadaan terhadap virus Covid 19. 


\section{Hasil dan Pembahasan}

Dari seluruh proses pengabdian yang dilakukan di peroleh beberapa hasil dan temuan pengabdian yakni masih banyak ditemukan masyarakat terdampak covid 19 yang tidak tersentuh bantuan sosial maupun kesehatan terutama masyarakat kurang mampu pada golongan lansia.Selanjutnya, melalui kegiatan bansos dan baksos setidaknya dapat memenuhi ketersedian pangan dalam hitungan perkiraan program bantuan pemerintah.Sedangkan penyemprotan desinfektan bermanfaat agar menjadi sarana pencegahan penyebarnya virus Covid 19.

Adapun faktor pendukung dan faktor penghambatFaktor pendukung dari kegiatan ini dengan tema "Bansos \& Baksos Bentuk Keperdulian Di Masa Pandemi Covid 19" yaitu pihak perangkat desa menganjurkan. Karena sama dengan program kerja yang ada di desa. Faktor pendukung lainnya yaitu persetujuan dosen pembimbing lapangan yang juga menyarankan proker ini. Sedangkan faktor penghambat yaitu terjadi kesalah pahaman. Mengenai komunikasi dan karena basis PKM di masa pandemi ini virtual. Pada nyatanya apabila tidak turun ke lapangan benar-benar keteteran program kerjanya. Ada apapula kegaguan dalam hal bersosialisasi bersama masyarakat sekitar dan pihak perangkat desa. Hal itu diakibatkan karena hanya salah pemahaman semata.

\section{Gerakan Bansos dan Baksos dalam konteks COVID 19}

Bantuan sosial atau biasa di singkat bansos adalah merupakan pemberian uang atau barang yang diberikan kepada masyarakat guna melindungi dari kemungkinan terjadinya resiko sosial dan untuk meningkatkan kesejahteraan masyarakat(Rahayu, 2012). Menurut Kementrian Sosial (2011), bantuan sosial adalah bantuan yang sifatnya sementara yang diberikan kepada masyarakat miskin, dengan tujuan untuk meningkatkan kehidupan secara wajar (Muga, Kiak, \& Maak, 2021). Program bantuan sosial merupakan salah satu program jaminan sosial yang bersifat realisasi bertanggungjawaban pemerintahan pemerintah pusat dan pemerintah daerah sebagai bentuk rasa pedulu terhadap masyarakat tingkat bawah. Program bantuan sosial adalah bentuk penerapan dari Undang-Undang Dasar 1945 pasal 34 ayat 1 yang berbunyi bahwa fakir miskin dan anak-anak terlantar dipelihara negara.

Secara legal formal juga terdapat pada penjelasan Undang-Undang Dasar 1945 Pasal 34 ayat 2 yang berbunyi negara mengembangkan sistem jaminan sosial bagi seluruh rakyat dan memperdayakan masyarakat yang lemah dan tidak mampu sesuai dengan martabatan kemanusiaan. Bansos dapat diberikan secara langsung kepada masyarakat atau lembagakemasyarakatan termasuk di dalamnya bantuan untuk lembaga non pemerintah bidang pendidikan dan keagamaan, sifatnya tidak terus menerus dan selektif. Dinas bansos bisa "dengan syarat" atau "tanpa syarat", diberikan melalui Kementerian/Lembaga, serta untuk bencana alam. Dari segi durasinya, bansos dapat bersifat sementara (untuk korban bencana), atau tetap (penyandang cacat), dan dapat berupa uang atau barang (Rahayu, 2012). APBN dikelompokan menjadi empat bidang yaitu: 
1) Bidang pendidikan meliputi Program BOS dan Bea Siswa Pendidikan Siswa /Mahasiswa Miskinub bagian ini berisi hasil penelitian. Hasil dapat disajikan dalam bentuk teks, tabel, dan interpretasi disertai dengan hasil yang dilaporkan. Tabel disertai dengan penomor nomor berurutan dan harus dikutip dalam isi teks.

2) Bidang kesehatan meliputi Program Jaskesmas dan Pelayanan Kesehatan di Rumah sakit kelas III.

3) Bidang Pemberdayaan Masyarakat (PNPM Perdesaan menckup Kecamatan PPK, P2KP, PNPM Perkotaan, PNPM Infrastruktur Perdesaan/PPIP, PNPM Daerah Tertinggal/PDT, PNPM Infrastruktur Sosial Ekonomi Wilayah).

4) Bidang Perlindungan Sosial, meliputi Program Keluarga Harapan/PKH, dan Bantuan Langsung Tunai/BLT (Rahayu, 2012; 2-3)

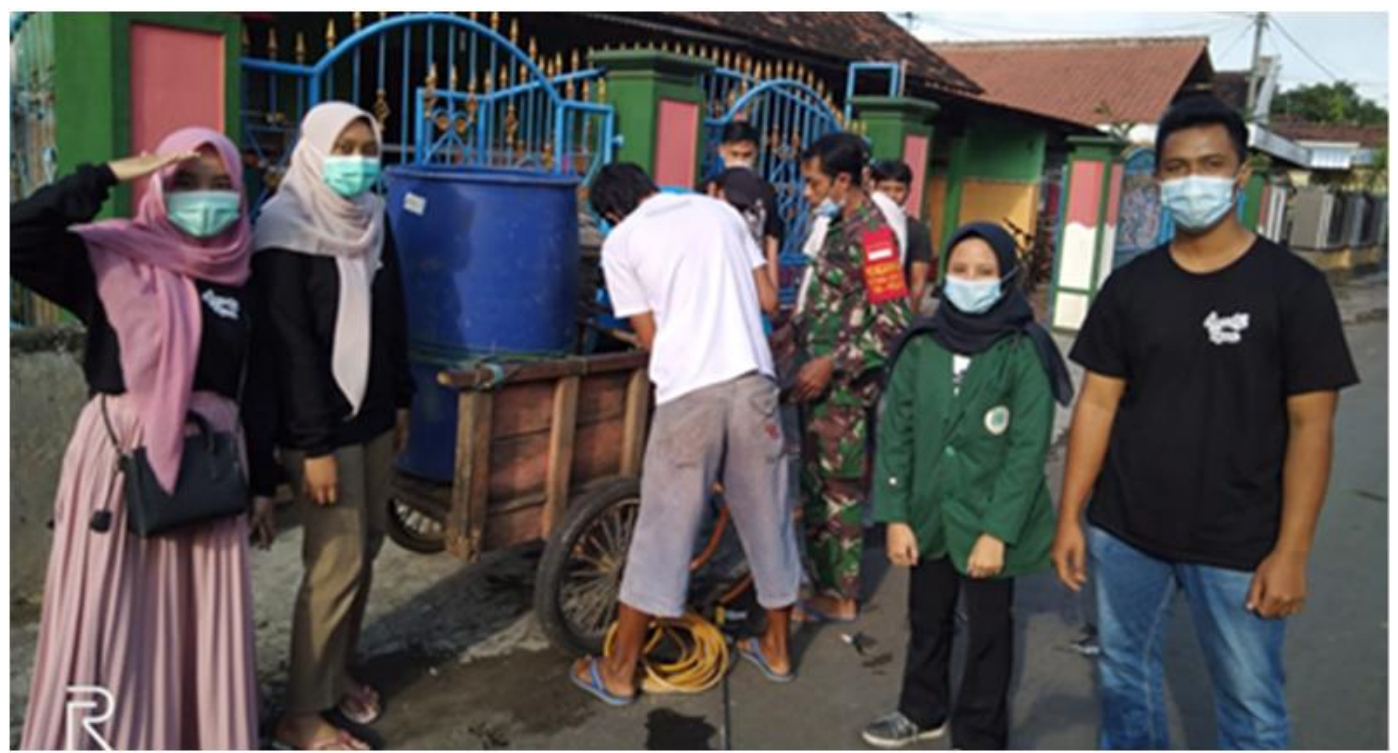

Gambar 1. Kegiatan Bansos Sembako

\section{Gerakan Kesehatan Masyarakat Melalui Desinfektan}

Desinfektan merupakan zat yang dapat membunuh patogen di lingkungan (Lachapelle, 2014). Desinfektan biasanya mengandung glutaraldehid dan formaldehid.Penggunaan zat-zat tersebut sebelumnya lebih menjadi tanggungjawab tenaga medis, namun untuk sekarang penggunaan zat-zat tersebut dapat digunakan tidak hanya di rumah sakit, namun di rumah pun akan sering digunakan (Upton, Lang, \& Heffernan, 2003).Jenis Antiseptik dan Desinfektan bermacam-macam menurut Lachenmeir :

1) Golongan aldehid: formaldehid, Glutaral

2) Golongan Guanid: Klorhexidine, poliheksametilen guanid

3) Cetrimide

4) Golongan senyawa benzalkonium

5) Etilen Oksida

6) Halogen

7) lodofosfor 
Dampak bila tidak digunakannya desinfektan sesuai dengan peruntukannya dapat yang paling umum adalah menimbulkan iritasi (Lachapelle, 2014). Iritasi yang dapat muncul adalah iritas kulit, jalur pernapasan, mata, dan dapat menimbulkan keracunan. Namun berdasarkan jenis-jenis antiseptik dandesinfektan tersebut tentunya memiliki bahayanya masing-masing jenisnya. Menurut Health Commission of the People's Republic of China (2020) terdapat prosedur rutin dalam penggunaan desinfektan yang dapat diterapkan:

1) Untuk permukaan objek dapat digunakan $1000 \mathrm{mg} / \mathrm{L}$ klorid danditambah dengan etanol $75 \%$ untuk bahan-bahan non korosi, setiap 4 jam.

2) Untuk udara dalam ruangan yang dicurigai terpapar, buka jendela atau pintu selama 30 menit. Semprotkan desinfektan yang mengandung klorin $1000 \mathrm{mg}$ dengan hati hati selama 2 kali seharidan tetap mengikuti prosedur keamanan.

3) Untuk tanah dapat diseka dengan desinfektan yang mengandung klorin $1000 \mathrm{mg}$, setiap 4 jam.

Pada masa pandemi ini, masyarakat banyak sekali yang berlomba-lomba untuk mendapatkan antiseptik dan desinfektan untuk mencegah penularan dan penyebaran Covid-19.Apabila sulit mendapatkan antiseptik maupun desinfektan, dapat dibuat dengan bahan-bahan yang sederhana.Menurut Profesor Arif Sumantri, cairan desinfektan dan antiseptik dapat dibuat dengan menggunakan bahan bersifat asam seperti cuka yang dicampurkan dengan bahan lain, hal ini dikarenakan cuka memiliki $\mathrm{pH}$ yang rendah namun bisa membunuh virus. Prosedur yang dilakukan adalah dapat mencampurkan setengah gelas cuka dengan setengah gelas air lalu ditambahkan sekitar 12-24 tetes minyak esensial seperti minyak kayu putih.

Selain itu, menurut WHO pun telah mengeluarkan panduan pembuatan HandSanitizer dengan menggunakan bahanbahan yaitu etanol atau isopropil alkohol, hidrogen peroksida 3\%, Gliserol 95\%, dan air destilasi atau air yang sudah di rebus dan didiginkan. Selain itu pemakaian desinfektan perlu diperhatikan dari segi takaran pembuatannya. Sebelum memulai mencampurkan bahan, pastikan menggunakan sarung tangan dan pakaian lengkap untuk menghindari kesalahan saat proses pencampuran. Jika keadaan pencampuran sudah aman, bisa dicampurkan pemutih pakaian sebanyak 1 sendok teh dengan 1 liter air. Takaran atau perbandingan ini dinilai aman digunakan untuk disemprotkan kepada benda mati yang akan disterilkan, serta tidak berbahaya dari segi bahan yang digunakan.

Covid-19, merupakan penyakit yang disebabkan oleh jenis virus corona yang menyerang ke sistem pernapasan.Virus corona sebenarnya pertama kali diidentifikasi pada tahun 1960-an. Umumnya virus ini ditemukan pada hewan dengan spesies yang berbeda-beda seperti unta, sapi, kucing, dan kalelawar.Namun yang terjadi saat ini merupakan jenis baru dari virus corona yaitu Covid-19.Penyakit ini telah mencapaikriteria epidemiologis yang sekarang disebut dengan pandemi yang mendunia karena telah berhasil menginfeksi lebih dari 100.000 orang di lebih dari 100 negara. Data yang didapatkan sekarang, di Indonesia terdapat sekitar 10.000 kasus yang terkonfirmasi dengan jumlah pasien sembuh sekitar 1000 dan meninggal 
647, sedangkan di seluruh dunia terkonfirmasi bahwa masyarakat yang terjangkit Covid-19 ini berjumlah sekitar 3 juta dengan jumlah pasien sembuh sebanyak 743 ribu dan jumlah meninggal sekitar 190 ribu. Dengan jumlah masyarakat yang terjangkit sebanyak ini perlu dilakukan adanya langkah pencegahan guna menghindarai penyebaran yang lebih luas lagi (Larasati, Gozali, \& Haribowo, 2020).

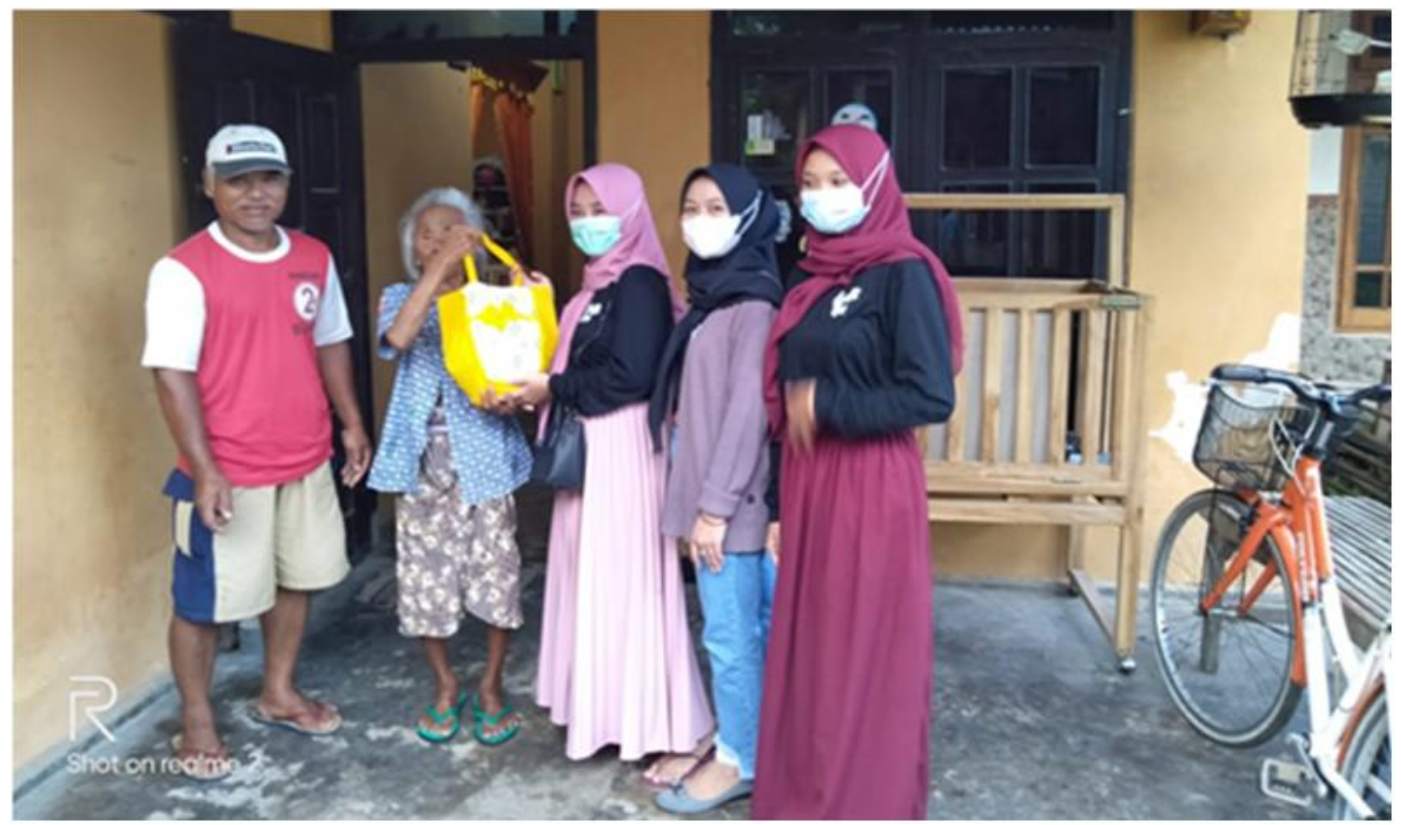

Gambar 2. Penyemprotan desinfektan bersama Kartar, Bhabinsa, dan Bhabinkamtipmas

Masyarakat masih banyak berpikir bahwa penularan Covid-19 masih bisa dihindari hanya dengan menjauhkan diri dari penderita saja, padahal penyakit ini dapat menyebar melaluipartikel-partikel yang menempel pada barang-barang disekitarnya. Virus dapat ditularkan dari 1 hingga 2 meter melalui batuk atau bersin. Cara transmisi virus yang lain adalah melaui kontak tangan, ataupun lingkungan yang terkena virus seperti gagang pintu, meja dan kursi. Sanitasi yang dapat dilakukan salah satunya adalah mencuci tangan serta muka dengan teratur. Apabila sanitasi tidak diperhatikan, maka penyebaran akan semakin luas. Dapat dimisalkan seseorang yang terjangkit virus covid bersin dan tidak ditutup baik dengan tisu ataupun diseka menggunakan lengan bagian dalam, dapat menularkan ke orangorang disekitarnya, atau jika seseorang yang terjangkit bersin lalu tanggannya memegang suatu benda yang ada di tempat umum dan orang lain memegangnya, dapat menimbulkan adanya transmisi penyakit (Jin et al., 2020). Dari hasil yang telah di dapat, dapat disimpulkan bahwa penggunaan antiseptik dan desinfektan untuk mencegah penularan Covid-19 efektif bila pemilihannya tepat serta digunakan sesuai dengan peruntukannya. Perlu adanya edukasi lebih lanjut oleh tenaga kesehatan kepada masyarakat guna menjadi tindakan pencegahan terhadap penyebaran lebih lanjut Covid-19 ini 


\section{Kesimpulan}

Pemberian bansos dan baksos kemasyarakatan harus berdasarkan atas peruntukannya secara spesifik telah ditetapkan dalam proposal, tidak wajib dan tidak mengikat, bersifat sementara dan tidak terus menerus setiap tahun anggaran, kecuali ditentukan lain oleh peraturan perundang-undangan dan memenuhi persyaratan menerima hibah. Berdasarkan hasil wawancara dan pengamatan peneliti pengunaan dana hibah dan bantuan sosial kemasyarakatan meliputi, rehab sosial, perlindungan sosial, pemberdayaan sosial, jaminanan sosial, penanggulangan bencana kemiskinan dan bencana. Berdasarkan hasil wawancara dan pengamatan penelitian penerapan dalam penelitian ini adalah penerapan implementasi kebijakan penyaluran hibah dan bantuan sosial kemasyarakatan. Realisasi berupa barang dan/atau jasa akuntansi pemerintahan pada laporan realisasi anggaran dan diungkapkan pada catatan atas laporan keuangan dalam penyusunan laporan keuangan pemerintah daerah, walaupun dalam pelaksanaanya masih kurang optimalnya sumber daya manusia.

Saran ntuk pelaksanaan PKM VDR kedepannya sosialisasi harus dilakukan di forum resmi dengan komitmen dan keterampilan pelaksana yang tinggi, materi yang disampaikan harus lengkap dan detail, sehingga dapat diterima masyarakat dengan jelas. Proses verifikasi data harus dilaksanakan sesuai dengan ketentuan yang berlaku, karena tujuan verifikasi data adalah untuk memperbaiki database dalam verifikasi penerima bantuan dan Sikap pelaksana petugas program bantuan sosial harus jelas dan tegas, dan tidak boleh terjadi pelanggaran

\section{Ucapan Terimakasih}

Rasa terimasih kami sampaikan kepada seluruh pihak; Bapak Kepala Desa Jati Mulyo, RT dan RW, Karangtaruna, Bhabinsa, dan Bhabinkamtipmas yang telah membantu terlaksananya kegiatan kemanusiaan dengan baik dan lancar meski ditemui keterbatasan dan hambatan. Selanjutnya kepada pihak LP2M UIN Sayyid Ali Rahmatullah yang secara konsisten dan keberlanjutan membuat program pengabdian untuk melatih seluruh tim pengbadian mencari pengetahuan dan pengalaman yang lebih baik.

\section{Referensi}

Jin, Y.-H., Huang, Q., Wang, Y.-Y., Zeng, X.-T., Luo, L.-S., Pan, Z.-Y., ... others. (2020). Perceived infection transmission routes, infection control practices, psychosocial changes, and management of COVID-19 infected healthcare workers in a tertiary acute care hospital in Wuhan: a cross-sectional survey. Military Medical Research, 7, 1-13.

Lachapelle, J. M. (2014). A comparison of the irritant and allergenic properties of antiseptics. European Journal of Dermatology, Vol. 24, pp. 3-9. https://doi.org/10.1684/ejd.2013.2198

Larasati, A. L., Gozali, D., \& Haribowo, C. (2020). Penggunaan Desinfektan dan Antiseptik Pada Pencegahan Penularan Covid-19 di Masyarakat. Majalah 
Farmasetika, 5(3), 137-145. https://doi.org/10.24198/mfarmasetika.v5i3.27066

Muga, M. P. L., Kiak, N. T., \& Maak, C. S. (2021). Dampak Penyaluran Bantuan Sosial Tunai Pandemi Covid-19 (Studi Kasus di Kelurahan Sikumana - Kota Kupang). OECONOMICUS Journal of Economics, 5(2), 105-112. https://doi.org/10.15642/oje.2021.5.2.105-112

Rahayu, S. L. (2012). Bantuan Sosial Di Indonesia. Bandung: Fokus Media.

Tapung, M. M., Regus, M., Payong, M. R., Rahmat, S. T., \& Jelahu, F. M. (2020). Bantuan sosial dan pendidikan kesehatan bagi masyarakat pesisir yang terdampak sosial-ekonomi selama patogenesis Covid-19 di Manggarai. Transformasi: Jurnal Pengabdian Masyarakat, 16(1), 12-26. https://doi.org/10.20414/transformasi.v16i1.2067

Tim Pengendali Pelaksanaan Penyaluran Bantuan Sosial secara Non Tunai. (2019). Pedoman Umum Program Sembako 2020. Jakarta: Kantor kementrian Kordinator Bidang Pembangunan Manusia dan Kebudayaan.

Upton, A., Lang, S., \& Heffernan, H. (2003). Mupirocin and Staphylococcus aureus: A recent paradigm of emerging antibiotic resistance. Journal of Antimicrobial Chemotherapy, 51(3), 613-617. https://doi.org/10.1093/jac/dkg127 